ISSN 2078-6441. Вісник Львівського університету. Серія географічна. 2013. Випуск 42. С. 333-341. Visnyk of the Lviv University. Series Geography. 2013. Issue 42. P. 333-341.

911.3:3:069 (477.83)

\author{
$\therefore$ \\ кс н тецюк ${ }^{1}$, т лія мк ло \\ 1 ввівський н ціон льний університет імені в н \\ вул. . орошенк , 41, 79000, м. ввів, кр їн \\ 2 ввівський регіон льний інститут держ вного упр вління \\ ціон льної $\kappa$ демії держ вного упр вління при резидентові кр їни, \\ вул. . ухомлинського, 16, 79491, м. ьвів- рюховичі, кр їн
}

$\mathrm{x}$ р ктеризов но тенденції т суч сний ст н розвитку мережі музейних 3 кл дів як скл дової системи туристичної інфр структури обл сті. изн чено перспективи т пріоритети розбудови й функціон льної орг ніз ції мережі музейних з кл дів у р йон х т міст х обл сного зн чення ьвівщини.

лючові слов : музеї, музейні фонди, гром дські музеї, екскурс нти, туристичн інфр структур , послуги музейних з кл дів.

кл ди культури т мистецтв є невіддільною скл довою туристичної інфр структури т м ють зн чний вплив н формув ння туристичної прив бливості регіонів кр їни.

узеї - в жливі осередки освіти і н вч ння, оскільки с ме вони з безпечують доступ до н ціон льної культурної т природної сп дщини дітям і дорослим. кскурсійні послуги, що їх н д ють укр їнські музеї, є обов'язковим компонентом туристичного продукту для іноземних т вітчизняних туристів.

ьвівщин - культурний і мистецький центр хідної кр їни. он посід $є$ одне 3 провідних місць в кр їні 3 кількістю музеїв і музейних кімн т. істо ьвів $\epsilon$ унік льним містом, яке толер нтно поєдн ло історію і культуру різних н родів т м $\epsilon$ зн чний культурно-туристичний потенці л. лизько півмільйон туристів т екскурс нтів упродовж ост нніх років відвідують місто ьвів т його музеї щорічно.

ш мет - про н лізув ти н явні тенденції розвитку музейних 3 кл дів різних 3 профілем т підпорядкув нням і виявити проблеми т перспективні н прями їхнього розвитку в $\mathrm{p}$ йон х і міст х обл сного зн чення ьвівщини.

ро зн чущість н укової, культурно-просвітницької т екскурсійно-туристичної функції музеїв хідного регіону кр їни з зн ч ли ще н поч тку ст. [14]. ині, н поч тку ст. м ємо всі підст ви стверджув ти, що музеї цього регіону перетворилися н невіддільну скл дову туристичного обслуговув ння й дед лі глибше інтегруються в туристичний бізнес.

озвитку н ціон льної музейної мережі, як в жливої скл дової туристичного обслуговув ння, присвячені пр ці . ейдик [1], . юбіцевої [7], . льської [8], . етр нівського, . утинського [11] т ін.

нформ ційною б зою дослідження є т кож офіційні ст тистичні д ні лужби ст тистики кр їни, оловного упр вління ст тистики в ьвівській обл., звітні т н літичні м тері ли іністерств культури кр їни, пр вління культури ьвівської обл сної держ вної дміністр ції.

(C) тецюк ., мк ло ., 2013 
обл сті історично скл л ся н йбільш розг лужен мереж 3 кл дів культури, що 3 кількістю т з г льнон ціон льним зн ченням посід є друге місце в кр їні після иєв . ьвівській обл. діють 14 головних музеїв т пон д 40 їхніх філій і відділів системи іністерств культури кр їни, з яких сім - обл сного підпорядкув ння ( ьвівський історичний музей, ьвівський музей історії релігії, ьвівський літер турномеморі льний музей в н р нк, еморі льний музей их йл рушевського у ьвові, сторико-кр єзн вчий музей м. инники, сторико-етногр фічний музей “ ойківщин ”, узей-с диб в н р нк у с. гуєвичі)

ьвівський історичний музей у структурі н лічує сім експозиційних відділів, які містяться в окремих споруд х чи з йм ють ч стину будівлі. ише один відділ є 3 меж ми ьвов - сторико-меморі льний музей вген онов льця у с. шків овківського р-ну.

о ьвівської г лереї мистецтв н лежить н йбільш кількість втономних відділів 12, з них сім у р йон х обл сті: узеї-з повідники “ леський з мок”, “ олочівський з мок”, “ ідгорецький з мок”; узей с диб . шкевич ( олочівський р-н, с. ідлисся), 'ятнич нськ веж ( ид чівський р-н, с. 'ятнич ни), узей в н иговського ( ид чівський р-н, с. уд ).

ціон льний музей у ьвові імені ндрея ептицького м є сім відділів: художній музей “ ок льщин ” у м. ервоногр д, художній музей “ ойківщин ” у м. мбір, художньо-меморі льний музей стияновичів у с. овків устомитівського р-ну, решт - у м. ьвів.

скл ді ьвівського музею історії релігії н лічують три відділи: художній музей “ юдин . емля. сесвіт” (м. ок ль), ервоногр дськ філія лц отоцьких (м. ервоногр д), музей-с диб родини нтоничів ( остиський р-н, с. ортянин).

еморі льний музей т нісл в юдкевич (м. ьвів) $є$ філією узичномеморі льного музею . рушельницької у м. ьвові.

з 50 головних держ вних музеїв т філій 30 розміщені у ьвові, решт - н території обл сті.

гідно 3 д ними річної звітності ст ном н 31 грудня 2011 р., кількість експон тів основного фонду головних музеїв обл сті ст новить 898838 одиниць, з них у музеях обл сного підпорядкув ння - 510150 п м'яток. ротягом року до головних музеїв обл сті н дійшло 12168 одиниць збережень, з них до музеїв обл сного підпорядкув ння - 9037 одиниць (див. рис. 1) [4].

підст ві н лізу роботи музеїв обл сті у 2011 р. можемо конст тув ти, що основні пок зники їхньої діяльності поліпшилися порівняно з 2010 р.

г льн кількість відвідув чів музеїв збільшил ся н 50 тис. осіб порівняно з 2010 р. окрем , у 2011 р. музеї обл сті відвід ло 1 520,6 тис. осіб, з них музеї обл сного підпорядкув ння - 631,9 тис. осіб.

йбільшу кількість відвідув чів у 2011 р. з фіксов но у ьвівському історичному музеї (р зом із відділ ми) - 353,6 тис. осіб, н другому місці - ьвівськ г лерея мистецтв (348,5 тис. осіб), третьому - узей н родної рхітектури т побуту у ьвові близько 300,0 тис. осіб (див. рис. 2).

більшил ся порівняно з 2010 р. і кількість проведених екскурсій у музеях обл сті. прикл д, 2011 р. у музеях обл сті проведено 21823 екскурсії, що н 1647 більше, ніж 2010 р. р цівники ьвівської г лереї мистецтв 2011 р. провели н йбільшу кількість екскурсій (6 839). 


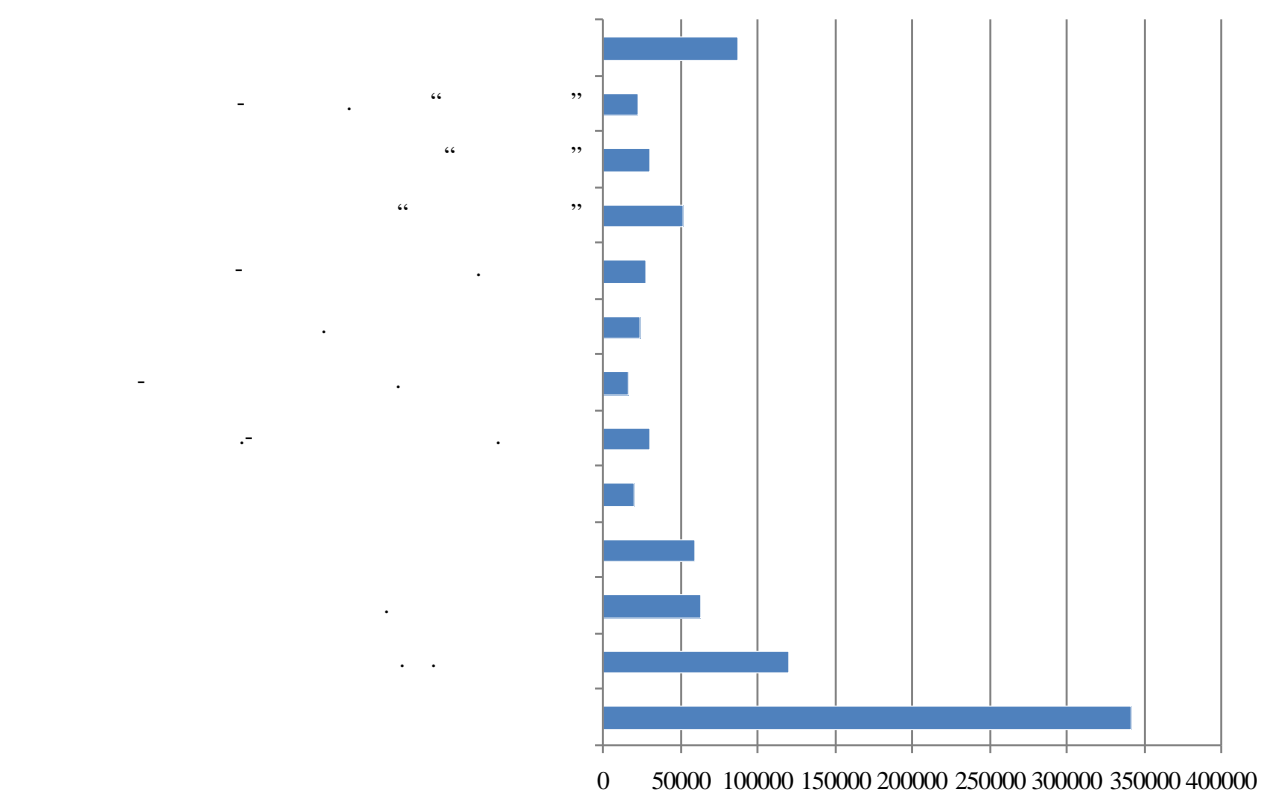

ис. 1. ількість експон тів музеїв ьвівщини, що перебув ють у підпорядкув нні іністерств культури, 2011 p.

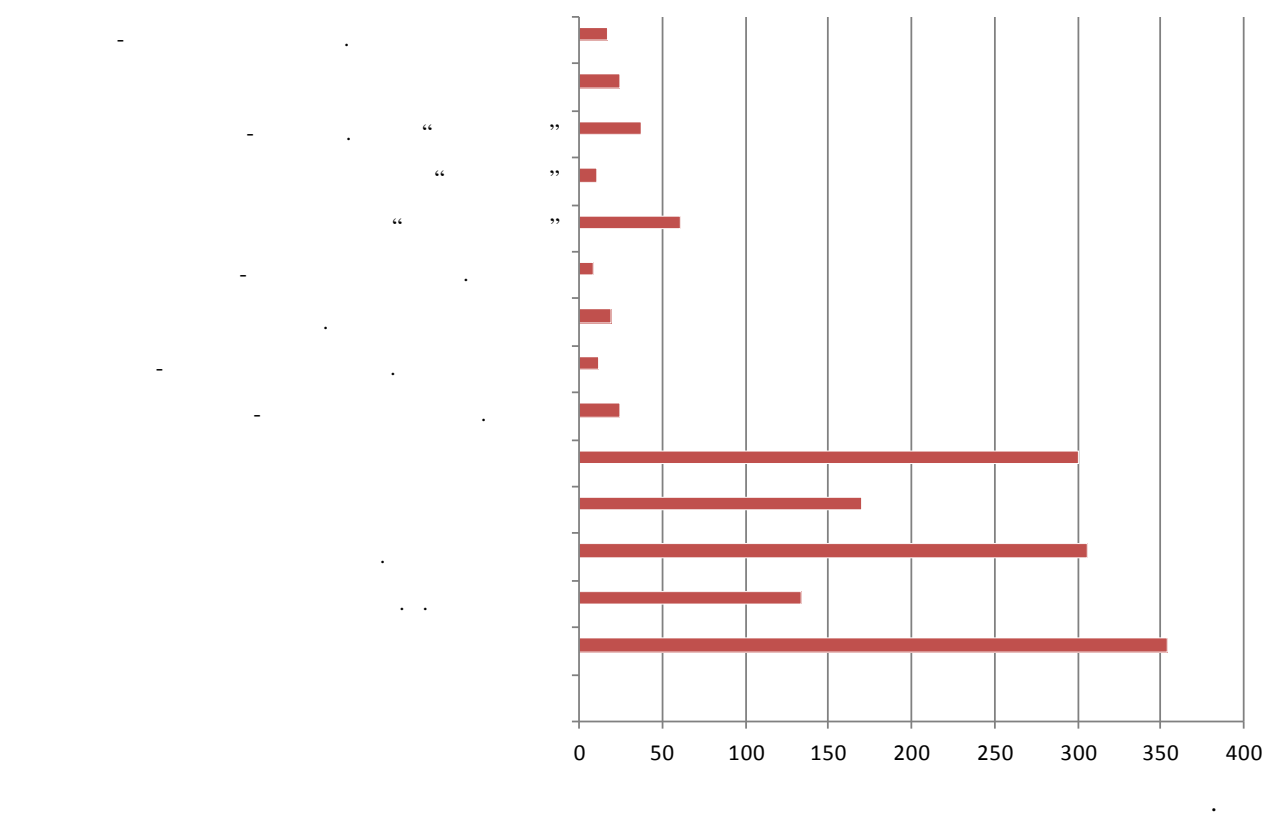

ис. 2. ідвідув ння музеїв ьвівщини, що перебув ють у підпорядкув нні іністерств культури, 2011 р. 
2011 р. музеї ктивно пр цюв ли в орг ніз ції вист вкової діяльності, було орг нізов но 392 вист вки (виїзні), що н 55 вист вок більше порівняно з 2010 р. [4].

тже, в обл сті впродовж 2009-2011 рр. простежув лося незн чне постійне зрост ння кількості відвідув чів т проведених екскурсій, що свідчить про з цік влення серед жителів обл сті й інших регіонів, т кож іноземних туристів музеями ьвівщини.

сновою будь-якого музею $є$ його фондов збірк т н уково-фондов робот . ількість експон тів основного фонду музеїв обл сті системи іністерств культури кр їни у 2010 р. ст новил 1 194,0 тис. одиниць зберіг ння. ондові збірки музеїв у 2010 р. поповнилися н 21,9 тис. одиниць. ількість експон тів основного фонду, які потребують рест вр ції, зросл н 3,2 тис. одиниць порівняно 32009 р. і в 2010 р. ст новил 96,6 тис. одиниць. кількість вист вок, відкритих упродовж року, порівняно з 2009 р. збільшил сь н 61 і ст новил 393 [4].

ідповідно до ост нови бінету іністрів кр їни від 2 лютого 2000 р. № 209 “ ро з твердження переліку музеїв, в яких зберіг ються музейні колекції т музейні предмети, що є держ вною вл сністю і н леж ть до держ вної ч стини узейного фонду кр їни", у ьвівській обл. до цього переліку н леж ть 50 держ вних музеїв, включ ючи їхні відділи (філії). они підпорядков ні іністерству культури кр їни, фін нсов ні із держ вного бюджету. це тільки в системі іністерств культури, не вр ховуючи відомчих музеїв, музеїв системи освіти, прив тних музеїв т г лерей.

очну кількість вітчизняних музеїв сьогодні неможливо визн чити, оскільки в кр їні нем чіткої системи обліку музеїв, крім того, музеї підпорядков ні різним відомств м, які не координують свою діяльність у цій сфері. дн 3 н г льних проблем розвитку музейної спр ви - створення єдиної суч сної інформ ційної б зи т єдиного координ ційного орг ну у цій г лузі. іністерстві культури існує лише невеликий відділ н лізу т прогнозув ння музейної спр ви.

ьвівській обл. із 50 держ вних музеїв н йбільше розміщено у ьвові - 30 з кл дів, рогобичі - 3 музеї, у ид чівському i ок льському р йон х, ервоногр ді по 2 музеї, у мборі, трию, уському, рогобицькому, олочівському, остиському, устомитівському, трийському і колівському р йон х - по 1 музею (див. т бл. 1).

о недерж вної ч стини узейного фонду кр їни н леж ть зібр ння музеїв, з снов них н інших форм х вл сності, у тому числі п м'ятки, що є вл сністю гром дських, релігійних орг ніз цій, окремих гром дян т їхніх об’єдн нь.

н шими дослідженнями, н йбільше гром дських музеїв (39 одиниць) розт шов но в обл сному центрі, нед ремно ьвів н зив ють містом музеїв, бо ж музеєм під відкритим небом. другому місці з кількістю гром дських музеїв $€$ устомитівський p йон (13 з кл дів), д лі - м. трий (11 музеїв). озподіл гром дських музеїв по території р йонів т міст обл сного зн чення відобр ж є т бл. 1.

тже, можемо викон ти т ке групув ння дміністр тивних одиниць ьвівської обл. 3 пок зником кількості музейних з кл дів, що прип д є н 10000 осіб мешк нців, у цьому р зі вр ховув тимемо і міст обл сного зн чення (див. т бл. 2).

одного музею не з фіксов но у м. оршин - курортному центрі обл сті. ише один гром дський музей є в урківському р-ні - родний музей “ ойківщин ”.

підст ві н лізу територі льного розподілу музеїв (з д ними н шого дослідження) по території обл сті з зн чимо т ке (див. рис. 3):

- серед дев'яти міст обл сного зн чення музеї функціонують н території восьми міст, н йвищий пок зник кількості музеїв н 10000 осіб у трию т орисл ві;

- н йбільш кількість держ вних т гром дських музеїв розт шов н у ьвові; 
- серед 20 дміністр тивних р йонів 3 кількістю музейних з кл дів т пок зником кількості музеїв н 10000 осіб лідирують трийський т уський р йон.

уський р-н відомий тим, що т м функціонує ерж вний музей-з повідник “ леський з мок”, н 6 зі музею “леський 3 мок” - відділ ьвівської г лереї мистецтв (відкрито 1975 р. після з вершення рест вр ції з мку).

кож н території р йону є історико-кр єзн вчі музеї у смт лесько, с. ути, смт р сне, сел х ур'я, околя, овосілки.

ьвівськ обл сть відігр є ключову роль у культурному житті з хідного регіону кр їни. оловними культурними центр ми обл сті, звич йно, $\epsilon$ ьвів, т кож уський, трийський, рогобицький, овківський т олочівський р йони.

узеї у р йон х т міст х обл сного зн чення ьвівщини

\begin{tabular}{|c|c|c|c|c|}
\hline \multirow[b]{2}{*}{ егіон } & \multirow{2}{*}{$\begin{array}{r}\text { ількість } \\
\text { музейних } \\
3 \text { кл дів }\end{array}$} & \multicolumn{2}{|c|}{ них } & \multirow{2}{*}{$\begin{array}{c}\text { ількість } \\
\text { музеїв н } \\
10000 \\
\text { мешк нців }\end{array}$} \\
\hline & & $\begin{array}{c}\text { держ вні } \\
\text { музеї }\end{array}$ & $\begin{array}{c}\text { гром дські } \\
\text { музеї }\end{array}$ & \\
\hline ьвів & 69 & 30 & 39 & 0,9 \\
\hline орисл в & 7 & - & 7 & 1,9 \\
\hline рогобич & 11 & 3 & 8 & 1,1 \\
\hline оршин & 0 & - & 0 & - \\
\hline овий озділ & 1 & - & 1 & 0,3 \\
\hline мбір & 6 & 1 & 5 & 1,7 \\
\hline трий & 12 & 1 & 11 & 2,0 \\
\hline руск вець & 3 & - & 3 & 1,01 \\
\hline ервоногр д & 4 & 2 & 2 & 0,5 \\
\hline родівський & 3 & - & 3 & 0,5 \\
\hline уський & 10 & 1 & 9 & 2,2 \\
\hline ородоцький & 7 & - & 7 & 1,01 \\
\hline рогобицький & 5 & 1 & 4 & 0,7 \\
\hline ид чівський & 7 & 2 & 5 & 1,01 \\
\hline овківський & 9 & 2 & 7 & 0,8 \\
\hline олочівський & 4 & 1 & 3 & 0,6 \\
\hline м'янко- узький & 2 & - & 2 & 0,3 \\
\hline икол ївський & 4 & - & 4 & 0,6 \\
\hline остиський & 6 & 1 & 5 & 1,04 \\
\hline еремишлянський & 1 & - & 1 & 0,2 \\
\hline устомитівський & 6 & 1 & 5 & 0,5 \\
\hline дехівський & 7 & - & 7 & 1,4 \\
\hline мбірський & 3 & - & 3 & 0,4 \\
\hline колівський & 1 & 1 & - & 0,2 \\
\hline ок льський & 7 & 2 & 5 & 0,7 \\
\hline т рос мбірський & 5 & - & 5 & 0,6 \\
\hline трийський & 14 & 1 & 13 & 2,2 \\
\hline урківський & 1 & - & 1 & 0,2 \\
\hline ворівський & 6 & - & 6 & 0,5 \\
\hline сього & 221 & 50 & 171 & 8,7 \\
\hline
\end{tabular}


озвиток мережі музейних з кл дів у р йон х і міст х обл сного зн чення ьвівської обл сті

\begin{tabular}{|c|c|c|}
\hline дміністр тивн одиниця & $\begin{array}{l}\text { ількість музеїв } \\
\text { н } 10000 \text { осіб }\end{array}$ & $\begin{array}{r}\text { івень розвитку } \\
\text { музейної мережі }\end{array}$ \\
\hline $\begin{array}{l}\text { ьвів, овий озділ, родівський, рогобиць- } \\
\text { кий, ид чівський, овківський, олочівський, } \\
\text { м'янко- узький, икол ївський, еремиш- } \\
\text { лянський, устомитівський, мбірський, } \\
\text { колівський, ок льський, т рос мбірський, } \\
\text { урківський, ворівський р йони }\end{array}$ & $0,01-1,0$ & езн чний \\
\hline $\begin{array}{l}\text { орисл в, рогобич, мбір, трий, руск вець, } \\
\text { ородоцький, остиський, дехівський р йони }\end{array}$ & $1,1-2,0$ & ередній \\
\hline уський, трийський р йони & он д 2,1 & ИсоКИЙ \\
\hline
\end{tabular}

лизько $31 \%$ музейних з кл дів ьвівщини всіх форм підпорядкув ння і вл сності зосереджено у ьвові. ут є н йвідоміші музеї обл сті із н йб г тшими музейними збірк ми, т кож н йліпші умови для розвитку музейної діяльності. істо відоме історичними подіями, споруд ми, культурною сп дщиною.

2011 р. ьвів міг ст ти культурною столицею вропи. престижне зв ння вропейської столиці культури ( $)$, яке д є величезний поштовх для розвитку, міст кр їн вросоюзу розпочин ють зм г ння з декільк років н перед. р зі перемоги місто отримує фін нсув ння упродовж кількох років н розвиток культурних проектів і перетворення міст н культурний і туристичний центр вропи [6].

пр во у 2016 р. отрим ти титул зм г лися п'ять польських міст: рш в , товіце, роцл в, д нськ і юблін. с ме юблін з пропонув в ьвову н цілий місяць перед ти зв ння вропейської столиці культури у р зі своєї перемоги. осі 3 титул ультурної столиці могли зм г тися тільки міст кр їн-членів вросоюзу. ніці тивн груп, як привел вже юблін до фін лу конкурсу, з пропонув л врокомісії іннов цію - розширення конкурсу н міст хідної вропи. ме тому для проекту було обр но ьвів - європейське місто, що опинилося поз меж ми кордонів . $\mathrm{p}$ во н титул у 2016 р. отрим ло м. роцл в. роте с м ф кт т кого розгляду озн ч $є$ визн ння н шого міст одним із шедеврів європейської культурної т музейної сп дщини.

тже, $з$ результ т ми н шого дослідження, в обл сті є 221 музейний 3 кл д (з д ними офіційної ст тистики - 140). ількість музеїв постійно зрост є.

обл сті впродовж 2009-2011 рр. простежув лося незн чне постійне зрост ння кількості відвідув чів т проведених екскурсій, що свідчить про з цік влення серед жителів обл сті т інших регіонів, іноземних туристів музеями ьвівщини.

йбільшу кількість відвідув чів у 2011 р. з фіксов но у ьвівському історичному музеї (р зом із відділ ми) - 353,6 тис. осіб, н другому місці - ьвівськ г лерея мистецтв (348,5 тис. осіб), третьому - узей н родної рхітектури т побуту у ьвові близько 300,0 тис. осіб.

ьвівській обл. із 50 держ вних музеї т філій, н йбільше є у ьвові (30 з кл дів), рогобичі (3 музеї), ид чівському i ок льському р йон х, ервоногр ді (по 2 музеї). 


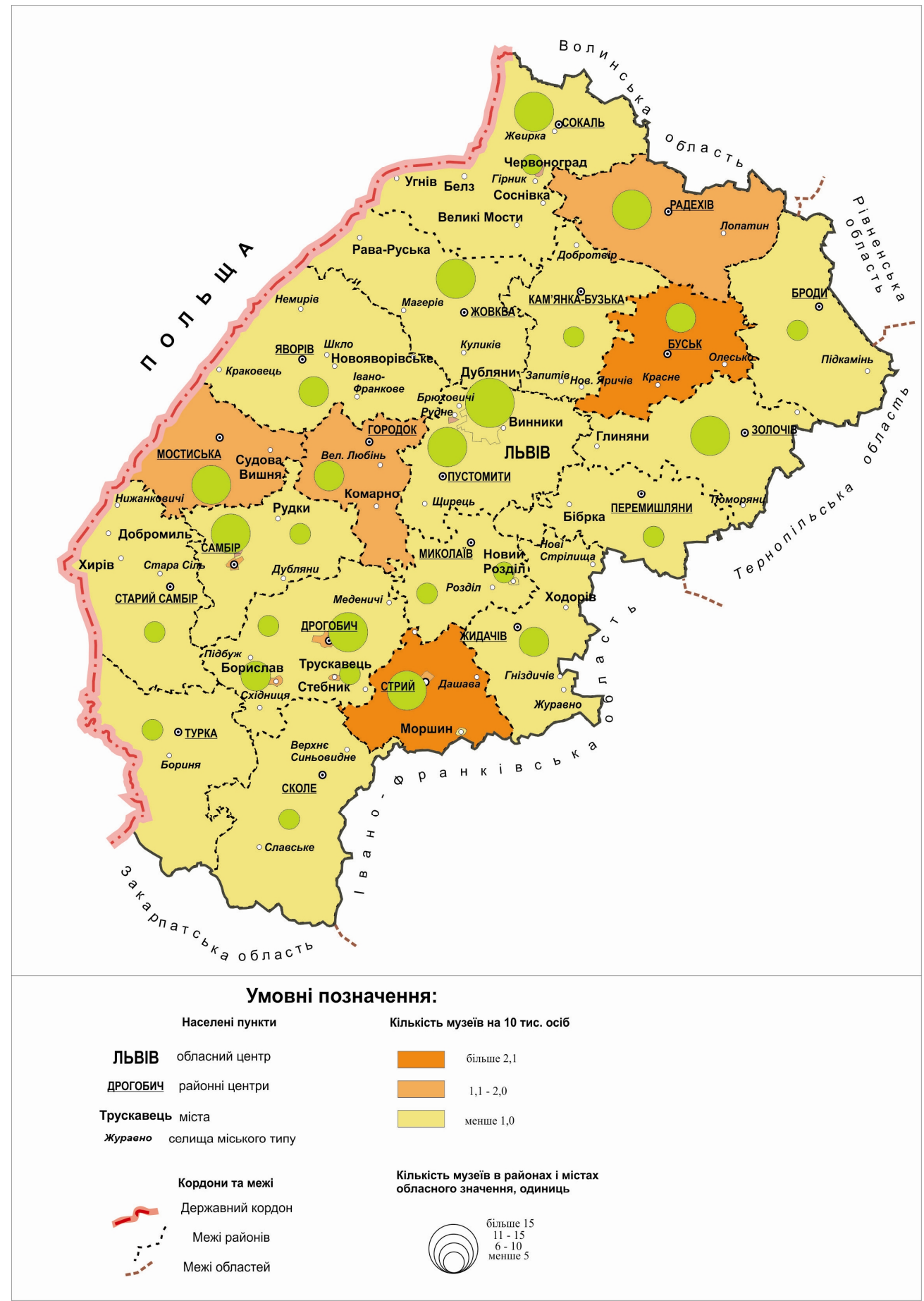

ис. 3. озвиток мережі музейних з кл дів ьвівщини. 
н шими дослідженнями, н йбільше гром дських музеїв (39 одиниць) розмішено у ьвові, зокрем, при н вч льних з кл д $\mathrm{x}$ i підприємств х. другому місці 3 кількістю гром дських музеїв - устомитівський $\mathrm{p}$ йон (13 з кл дів), д лі м. трий (11 музеїв).

еред дев'яти міст обл сного зн чення музеї функціонують н території восьми, н йвищий пок зник кількості музеїв н 10000 осіб у м. трий т м. орисл в; н йбільш кількість держ вних т гром дських музеїв розт шов н у ьвові; 3 кількістю музейних з кл дів т пок зником кількості музеїв н 10000 осіб лідирують трийський т уський р йони.

оловн проблем гром дських музеїв - відсутність н лежного фін нсув ння т нез хищеність. ст нніми рок ми зрост є кількість гром дських музеїв п тріотичного спрямув ння. сновними проблем ми розвитку музейної сфери у ьвівській обл. є: відсутність єдиної суч сної інформ ційної б зи т єдиного координ ційного орг ну в цій г лузі; нест ч фін нсув ння, що нег тивно позн ч ється н можливості експонув ння, збереження т збільшення музейних фондів; нест ч профільних ф хівців; низький рівень опл ти пр ці в г лузі.

ріоритетними н прям ми діяльності щодо розвитку музеїв є збереження н ціон льно-культурного н дб ння т вдоскон лення н явної мережі; розробк і впров дження іннов ційних підходів до музейного будівництв ; інтегр ція музеїв ьвівщини у світовий культурний простір; проведення необхідних рест вр ційних робіт музейних фондів; з пров дження нових форм музейної роботи, перевірк обліку т зберіг ння музейних предметів т колекцій; створенням електронного к т логу музейних фондів.

1. ейдик . . екре ційно-туристські ресурси кр їни: методологія т методик н лізу, термінологія, р йонув ння / . ейдик. - ., 2001. - 395 с.

2. оловне упр вління ст тистики у ьвівській обл сті. [ нтернет ресурс] - ежим доступу: http://lv.ukrstat.gov.ua/

3. ром дські музеї ьвівщини : [довідник] : у 2 т. / вт.-упоряд.: . ерейм , . гоновськ, . обків, . в новськ ; ьвівський історичний музей. - ьвів : ром н, 2007. - . 1. - 243 с. : іл.

4. нформ ційно- н літичний звіт пр вління культури ьвівської обл сної держ вної дміністр ції з 2011 рік (м тері ли до колегії). - 2012. - 108 с.

5. омплексн стр тегія розвитку ьвов 2012-2025 рр.: [ лектронний ресурс]. ежим доступу: http://www.city-institute.org/images/stories/files/strategy_last.pdf.

6. ультур і туризм у ьвові. фіційний туристичний с йт міст ьвов : [ лектронний ресурс]. - ежим доступу: http://www.cultureandtourism.lviv.ua/uk/tourism/

7. юбіцев . . инок туристичних послуг (геопросторові спекти) / . . юбіцев . - . : льтерпрес, 2002. - 436 с.

8. льськ . . іжн родний туризм i сфер послуг: [підручник] / . . льськ, . . нтонюк, . . н нич. - . : н ння, 2008. - 661 с.

9. льськ . . отельний бізнес: теорія т пр ктик / . . льськ , . . ндяк. - . : 2010. -472 с.

10. Orlowicz . Ilustrowany Przewodnik po Lwowie. - Lwow-Warszawa, 1925. - 274 s.

11. етр нівський . . уристичне кр єзн вство : [н вч. посібник] / . . етр нівський, . . утинський / ред. проф. . . ст вного. - . : н ння, 2006. - 570 с. 
12. утинський . . узеєзн вство : [н вч. посібник] / . . утинський, . . тецюк. - . : н ння, 2008. - 428 с.

13. екре ційний потенці л ьвівщини. т тистичний збірник / оловне упр вління ст тистики у ьвівській обл сті. - ьвів, 2011. - 98 с.

14. венціцький . ро музеї і музейництво / . венціцький. - ьвів, 1920. - 79 с.

15. т тистичний щорічник кр їни з 2009 рік / [ред. . с уленко]. - . : онсульт нт, 2010. - $567 \mathrm{c}$.

16. т тистичний щорічник кр їни з 2010 рік / [ред. . с уленко]. - . : онсульT HT, 2011. $-572 \mathrm{c}$.

m ття: н дійшл до ред кції 03.07.2013

доопр иьов н 25.07.2013

прийнят до друку 10.10.2013

\title{
MUSEUM NETWORK OF LVIV REGION: TERRITORIAL TRENDS OF PROGRESS
}

\author{
Oksana Stetsyuk ${ }^{1}$, Natalia Hamkalo ${ }^{2}$ \\ ${ }^{I}$ Ivan Franko National University of Lviv, \\ P. Doroshenko St., 41, UA - 79000 Lviv, Ukraine \\ ${ }^{2}$ The Lviv Regional Institute of Public Administration \\ National Academy of Public Administration, the Office of the President of Ukraine, \\ V. Sukhomlynksyy St., 16, UA - 79491 Lviv-Bryuhovychi, Ukraine
}

In the article the trends and current status of development of the museum network institutions as part of a system of tourist infrastructure are investigated in the Lviv region. The perspectives and priorities of development and functional organization of the museum network are expected in the districts and towns of regional status.

Key words: museums, museum collections, public museums, tourists, tourist infrastructure, services of museum institutions.

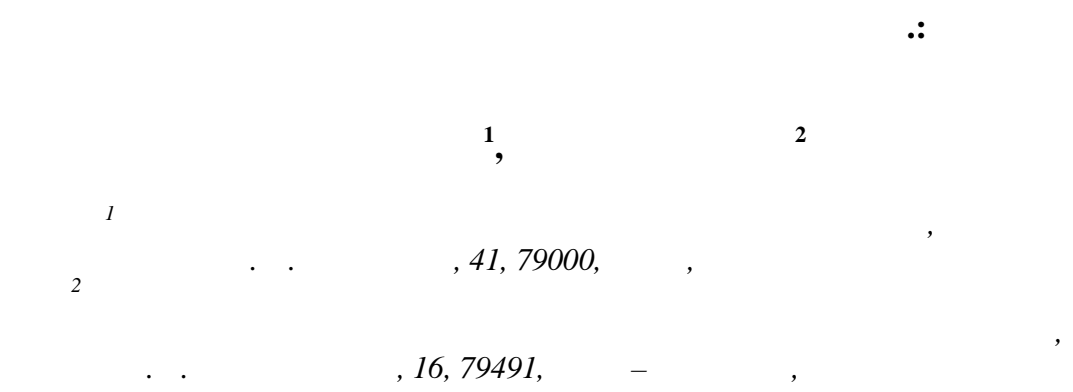

пис но тенденции и текущее состояние $\mathrm{p}$ звития сети музейных учреждений в $\mathrm{p}$ мк $\mathrm{x}$ системы туристической инфр структуры в регионе. пределено проблемы, приоритеты р звития и функцион льной орг низ ции сети музейных учреждений в р йон х и город х обл стного зн чения ьвовщины.

лючевые слов : музеи, музейные фонды, общественные музеи, туристы, туристическ я инфр структур , услуги музейных учреждений. 